Barr \& Johnson (2021)

\title{
ANSERJ
}

Vol. 12, No. S1

Autumn / automne 2021

pp. $91-96$

Canadian Journal of Nonprofit and Social Economy Research

Revue canadienne de recherche sur les OSBL et l'économie sociale

\section{National Nonprofit Sector Advocacy During the COVID-19 Pandemic}

\author{
Cathy Barr \& Bernadette Johnson \\ Imagine Canada
}

\begin{abstract}
When the COVID-19 pandemic hit Canada in March 2020, charitable and nonprofit sector leaders quickly realized the survival of many organizations was at risk. Three national coalitions formed to seek support for the sector from the federal government. Their efforts produced several concrete policy outcomes, including the inclusion of charities and nonprofits in all major federal relief programs and two support programs designed for charities and nonprofits. They also contributed to significantly increased awareness among policymakers of the role and challenges of charities and nonprofits. This has opened a policy window that the sector can use to advance several long-standing goals.

\section{RÉSUMÉ}

Quand la pandémie du COVID-19 a frappé le Canada en mars 2020, les dirigeants du secteur caritatif et sans but lucratif se sont vite rendu compte que la survie de plusieurs organismes était menacée. On a donc formé trois coalitions nationales afin de chercher un appui au secteur auprès du gouvernement fédéral. Les efforts de ces coalitions ont mené à plusieurs politiques concrètes, y compris l'inclusion d'organismes de bienfaisance et sans but lucratif dans tous les programmes d'aide fédéraux majeurs et la création de deux programmes d'aide conçus spécifiquement pour les organismes de bienfaisance et sans but lucratif. Ces coalitions ont aussi contribué à accroître de manière significative la conscience parmi les stratèges du rôle et des défis des organismes de bienfaisance et sans but lucratif. Ces progrès ont créé des occasions politiques dont le secteur pourra profiter pour faire avancer plusieurs objectifs de longue date.
\end{abstract}

Keywords / Mots clés: Advocacy; Nonprofit; Charity; Public policy; COVID-19 / Défense des droits; Organisme sans but lucratif; Organisme de bienfaisance; Politiques publiques; COVID-19

\section{INTRODUCTION}

When the COVID-19 pandemic hit Canada in March 2020, charities and nonprofits across the country were faced with challenges few had ever anticipated. Almost overnight, staff moved out of offices and into living rooms, dining rooms, and kitchens. Events of all kinds, from local fundraising galas to regional festivals and national conferences, were cancelled. Thriving volunteer programs came to a screeching halt. Some organizations scrambled to move their programs and services online; others searched for personal protective equipment and renovated their space so they could continue 


\section{Barr \& Johnson (2021)}

providing services in person; some had to shut down entirely. Amid this upheaval, sector leaders recognized immediately that the survival of many organizations was at risk. This led them to come together, at least for a time, to advocate for a small number of shared goals. Although their efforts were far from completely successful, they produced several concrete policy outcomes. They also contributed to significantly increased awareness among policymakers of the role and challenges of charities and nonprofits. This has opened a policy window (Howlett, 1998; Kingdon, 1984) the sector can use to advance several long-standing goals.

\section{ADVOCACY EFFORTS}

In the early days on the pandemic, three national coalitions emerged seeking support for the charitable and nonprofit sector. Imagine Canada, the national umbrella organization for charities and nonprofits, led one coalition; War Child Canada, an international aid agency, led the Emergency Coalition of Canadian Charities; and Cardus, a think tank with Christian roots, led the Canada Cares Coalition. The coalition led by Imagine Canada had more than 200 members and included many large national organizations and federations. It asked for an \$8 billion emergency stabilization fund, eligibility for charities and nonprofits in federal initiatives aimed at helping employers retain staff, flexibility in existing federal funding agreements, the suspension of rules that limit who charities can fund; and the creation of a governmentsector table to share advice and ideas (Imagine Canada, 2020c). The Emergency Coalition of Canadian Charities had 140 to 160 members and included many of the same organizations as the Imagine Canada coalition. Three of its five asks were similar: a $\$ 10$ billion stabilization fund, access for charities to the same recovery programs available to businesses, and flexibility in funding agreements. Unlike the Imagine Canada group, the Emergency Coalition also asked for loan guarantees and a temporary increase in the Charitable Donation Tax Credit (War Child Canada, 2020). The membership of the Canada Cares Coalition differed significantly from the membership of the other two groups. A large proportion of its approximately 130 member organizations were small, locally focused organizations and many were religious organizations or organizations with religious roots. The Canada Cares Coalition focused exclusively on advocating for a one-to-one donation matching program.

The Emergency Coalition of Canadian Charities was the first of the three coalitions to issue a news release and it had significant success in getting mainstream media coverage of it (see Ferreira, 2020; Jackson, 2020; Keung, 2020; Northcott, 2020; Posadzki, 2020). This success was most likely due to the high-profile and media connections of the coalition's leader, War Child Canada President Samantha Nutt. The group also wrote an open letter to the prime minister and held meetings and phone calls with government officials. Its direct lobbying efforts did not meet with immediate success, however, and after not much more than a month of activity, War Child Canada withdrew from a leadership role in sector-wide advocacy.

The Canada Cares Coalition was somewhat slower off the mark than the Emergency Coalition, but it developed a more detailed policy proposal, used a wider variety of advocacy tactics, and kept up its efforts for much longer. In addition to issuing news releases and engaging in media-relations and government-relations activities, it established a website (Canada Cares, n.d.-a) and a social media presence. It also actively encouraged charities to join the campaign, share their support on their own social media channels, and write their Member of Parliament. Finally, it used research to support its policy proposal (Canada Cares, n.d.-c) and public opinion polling to support its advocacy efforts. Canada Cares advocated for a donation matching program for more than a year, ceasing activity only after the federal government's 2021 budget was delivered. The last statement from the group, issued April 19, 2021, expressed disappointment that the budget did not include a donation matching program (Canada Cares, n.d.-b).

The coalition led by Imagine Canada used the widest array of advocacy tactics and persisted for the longest period. Its initial news release (Imagine Canada, 2020a) was issued one day after that of the Emergency Coalition and did not attract 


\section{Barr \& Johnson (2021)}

the same amount of attention from the media. The data analysis it provided to support its proposals (Imagine Canada, 2020b), however, helped it garner attention a few days later. A Canadian Press article was picked up by more than 180 print and broadcast media outlets across the country (see, for example, Press, 2020a, 2020b) and the data were cited in approximately 60 additional media stories. Roughly 60 radio and television stories followed over the next two weeks, many featuring interviews with Imagine Canada CEO Bruce MacDonald. Aside from its media campaign, the Imagine Canada coalition held meetings and phone calls with government officials and conducted multiple letter-writing and social media campaigns. It also made extensive use of survey results to support its advocacy efforts (Imagine Canada, 2021; Lasby, 2020, 2021; Lasby \& Barr, 2021). Finally, Imagine Canada created a COVID-19 hub on its website, which it used to publicize its advocacy activities; share stories and research on the impact of the pandemic on the sector; and share information about ever-evolving federal support programs. At the time of writing, the hub was still being updated regularly.

\section{POLICY OUTCOMES}

Although the sector was not successful in obtaining its most high-profile asks-a stabilization fund and donation matching program -its efforts produced several concrete policy outcomes that helped thousands of organizations continue to operate, employ staff, and deliver services throughout the pandemic. These included two programs designed specifically for charities and nonprofits. The Emergency Community Support Fund, launched in the spring of 2020, provided $\$ 350$ million for charities and nonprofits that offer essential services to vulnerable populations (Prime Minister's Office, 2021a). The Community Services Recovery Fund, announced in the 2021 federal budget, will provide $\$ 400$ million to help charities and nonprofits adapt and modernize (Canada. Department of Finance, 2021). Millions of dollars in targeted support were also provided to food banks; seniors' organizations; women's shelters; sexual assault centres; mental health organizations; arts, culture, and sports organizations; and organizations led by and serving Black Canadians.

In terms of the amount of funding involved, the most significant victory was the inclusion of charities and nonprofits in all major federal COVID-19 relief programs, including the Temporary Wage Subsidy for Employers, Canada Emergency Wage Subsidy, Canada Emergency Commercial Rent Assistance, Canada Emergency Rent Subsidy, and Canada Emergency Business Account. The Canada Revenue Agency estimates that, to date, charities and nonprofits have received between $\$ 3.7$ and $\$ 4.1$ billion through the Canada Emergency Wage Subsidy alone (Canada Revenue Agency, personal communication, October 4, 2021). The inclusion of charities and nonprofits in programs developed to support employers was not a foregone conclusion. They were not included in programs developed to help businesses during the 2008-2009 financial crisis, and when the prime minister first laid out the government's response to the pandemic, they were not mentioned (Prime Minister's Office, 2020b). In fact, concerted efforts were required to ensure charities and nonprofits were eligible for these general support programs. It is worth noting, however, that they were included automatically in the more recently developed Sector Workforce Solutions Program and Canada Recovery Hiring Program. This suggests that an understanding that charities and nonprofit are employers as well as service providers may finally have penetrated the corridors of Ottawa.

Another important development occurred in January 2021, when the Minister of Families, Children and Social Development was given a mandate to "continue to work across government to ensure that charities and non-profits have the tools that they need to modernize as they emerge from the pandemic to support the Government's overall agenda in a manner that responds to the needs of Canadians in every region" (Prime Minister's Office, 2021, para. 16). In this way, the government signalled that the sector was officially on its agenda and assigned the Department of Employment and Social Development to be the de facto "home in government" for the sector-at least for now. The wording of the mandate letter also indicates a growing understanding in government circles of both the role of the charitable and nonprofit sector and its challenges. 


\section{Barr \& Johnson (2021)}

The governing party was not alone in developing more awareness of the sector during the pandemic. In March 2021, the House of Commons debated an opposition motion calling on the government to include measures to support the charitable sector in the upcoming budget (Canada. Parliament, 2021). The motion, which was introduced by the Conservative Party, passed with support from all four opposition parties. The number and nature of interventions in the House since March 2020 also show growing awareness of, and interest in, the sector among elected representatives of all political stripes. Imagine Canada tracks interventions in the House that mention the sector. Prior to the pandemic, such mentions were exceedingly rare, amounting to no more than a handful a year. From the date the pandemic was declared to the end of June 2021, the House sat for 143 days; in that time, there were at least 150 separate interventions that mentioned the sector. Many of these involved Members of Parliament speaking about the contributions of charities and nonprofits in their communities, but others raised key policy issues such as program eligibility and the need for core funding.

The clearest indication of the government's changed perspective on the sector came in the recent federal budget. Budget 2021 has been called "significant and historic" (Syed, 2021, para. 1), "monumental" (Syed, 2021, para. 2), and "a huge victory" (Syed, 2021, para. 10) for the sector. There are several reasons for this view, including the strong emphasis on not-for-profit childcare contained in the government's commitment to spend $\$ 30$ billion over five years to create a national early learning and childcare system. The main reason, though, is that the budget explicitly recognized, for the first time, the importance of the sector and the government's responsibility to support it. "Canada's charities, non-profits, social enterprises, and other organizations provide vital services to our communities, including to the most vulnerable members of Canadian society. ... As we navigate our recovery, we must also bolster Canada's thriving social sector so that we can build healthy, resilient, and inclusive communities across the country" (Canada. Department of Finance, 2021, p. 206).

\section{CONCLUSION}

Many factors came together during the COVID-19 pandemic to change the way policymakers view and interact with the charitable and nonprofit sector. Key factors included the uneven impact of the pandemic on groups that comprise a large portion of sector workers and beneficiaries (e.g., women, low-wage workers, immigrants, racialized communities), the focus on racial justice brought about by Black Lives Matter and the discovery of unmarked graves at the Kamloops Indian Residential School, and the tireless efforts of charities and nonprofits that worked every day under difficult conditions to provide services and supports to Canadians. However, the sector's advocacy efforts cannot be discounted. From almost every perspective, the past 18 months have been one of the most active ever for the sector and this work has paid off in terms of policy outcomes.

In the next few years, the sector can use the policy window opened by the pandemic to advance key, long-standing policy goals. These include establishing a "home" for the sector within the federal government, developing fairer and more effective funding and accountability mechanisms, changing the rules that make it difficult for charities to partner with noncharities, and collecting more and better data about the sector. Whether it can capitalize on this opportunity, of course, remains to be seen.

\section{REFERENCES}

Canada. Department of Finance. (2021). Budget 2021: A recovery plan for jobs, growth, and resilience. URL: https:// www.budget.gc.ca/2021/home-accueil-en.html [October 20, 2021].

Canada. Parliament. (2021, March 9). House of Commons debates. Hansard 150(069). 43rd parliament, 2nd session.

URL: https://publications.gc.ca/collections/collection_2021/parl/X3-432-69-eng.pdf [October 3, 2021].

Canada Cares. (n.d.-a). Canada Cares. URL: https://www.canadacarescampaign.ca/ [September 30, 2021]. 


\section{Barr \& Johnson (2021)}

Canada Cares. (n.d.-b). Canada Cares statement: 2021 federal budget. URL: https://www.canadacarescampaign.ca /news/federalbudget2021 [September 30, 2021].

Canada Cares. (n.d.-c). The policy idea. URL: https://www.canadacarescampaign.ca/the-policy-idea [September 30, 2021].

Ferreira, J. (2020, March 26). Canadian charities call for \$10-billion stabilization amid COVID-19 crisis. CTV News.

URL: https://www.ctvnews.ca/canada/canadian-charities-call-for-10-billion-stabilization-fund-amid-covid-19-crisis-1 .4869583 [October 1, 2021].

Howlett, M. (1998). Predictable and unpredictable policy windows: Institutional and exogenous correlated of Canadian federal agenda-setting. Canadian Journal of Political Science 31(3), 495-524.

Imagine Canada. (2020a, March 26). COVID-19 threatens to devastate Canada's charities [News release]. Toronto, ON: Imagine Canada. URL: https://www.imaginecanada.ca/en/360/covid-19-threatens-devastate-canadas-charities [September 21, 2021].

Imagine Canada. (2020b, March 24). Forecasted economic impacts of coronavirus on the charitable sector in 2020. Toronto, ON: Imagine Canada. URL: https://imaginecanada.ca/sites/default/files/2020-03/ForecastedEconomic ImpactsCoronavirus_English.pdf [September 21, 2021].

Imagine Canada. (2020c, March 23). Letter to government. Toronto, ON: Imagine Canada. URL: https://www.imagine canada.ca/sites/default/files/Letter-to-Government-March-23-2020.pdf [October 20, 2021].

Imagine Canada. (2021). The ongoing COVID-19 experience of Canadian charities. Toronto, ON: Imagine Canada. URL: https://www.imaginecanada.ca/sites/default/files/Sector-Monitor-report-highlights-2021.pdf [September 28, 2021].

Jackson, H. (2020, March 29). "It's critical": More than 200 charities call on feds for funding amid COVID-19. Global News. URL: https://globalnews.ca/news/6747825/coronavirus-charities-canada/ [October 1, 2021].

Keung, N. (2020, March 25). Canadian charities seek $\$ 10$ billion lifeline as COVID-19 threatens "irreparable collapse." Toronto Star. URL: https://www.thestar.com/news/canada/2020/03/25/canadian-charities-seek-10-billion-emergency -lifeline-as-covid-19-threatens-irreparable-collapse.html [October 1, 2021].

Kingdon, J.W. (1984). Agendas, alternatives and public policies. Boston, MA: Little Brown.

Lasby, D. (2020). Imagine Canada's sector monitor: Charities and the COVID-19 pandemic. Toronto, ON: Imagine Canada. URL: https://imaginecanada.ca/sites/default/files/COVID-19\%20Sector\%20Monitor\%20Report\%20 ENGLISH_0.pdf [September 28, 2021].

Lasby, D. (2021). Imagine Canada's sector monitor: Ongoing effects of the COVID-19 pandemic. Toronto, ON: Imagine Canada. URL: https://www.imaginecanada.ca/sites/default/files/Sector-Monitor-Ongoing-Effects-COVID-19Pandemic-EN.pdf [September 28, 2021].

Lasby, D. \& Barr, C. (2021). Imagine Canada's sector monitor: The uneven impact of the pandemic on Canadian charities. Toronto, ON: Imagine Canada. URL: https://imaginecanada.ca/sites/default/files/Sector-Monitor-Theuneven-impact-of-the-pandemic-on-Canadian-charities.pdf [September 28, 2021].

Northcott, A. (2020, March 27). "Stand strong": Charities brace for a lean season as pandemic cuts into donations, volunteer base. CBC News. URL: https://www.cbc.ca/news/canada/montreal/covid19-charity-ngo-canada-montreal -1.5513086?utm_source=The+Philanthropist\&utm_campaign=aaae89364c-EMAIL_CAMPAIGN_2020_04_07_01 _33\&utm_medium=email\&utm_term=0_5ad5e4eaea-aaae89364c-69569553 [October 1, 2021].

Posadzki, A. (2020, March 26). Canadian charities call for \$10-billion stabilization fund to weather coronavirus crisis. Globe and Mail. URL: https://www.theglobeandmail.com/business/article-canadian-charities-call-for-10-billion -stabilization-fund-to-weather/ [October 1, 2021].

Press, J. (2020a, March 30). As feds help businesses, charities seek help to keep services running. CTV News. URL: https://www.ctvnews.ca/health/coronavirus/as-feds-help-businesses-charities-seek-help-to-keep-services-running -1.4874120 [September 22, 2021]. 


\section{Barr \& Johnson (2021)}

Press, J. (2020b, March 30). Charities seek extra help from feds to keep services running as revenues dry up. Toronto Star. URL: https://www.thestar.com/business/2020/03/30/as-feds-help-businesses-charities-seek-help-to-keep -services-running.html [September 22, 2021].

Prime Minister's Office. (2020a, April 21). Prime Minister announces further support to help Canadians in need [News release]. Ottawa, ON: Prime Minister's Office. URL: https://pm.gc.ca/en/news/news-releases/2020/04/21/prime -minister-announces-further-support-help-canadians-need [October 20, 2021].

Prime Minister's Office. (2020b, March 11). Prime Minister outlines Canada's COVID-19 response [News release]. Ottawa, ON: Prime Minister's Office. URL: https://pm.gc.ca/en/news/news-releases/2020/03/11/prime-minister -outlines-canadas-covid-19-response [October 3, 2021].

Prime Minister's Office. (2021, January 15). Minister of Families, Children and Social Development supplementary mandate letter. Ottawa, ON: Prime Minister's Office. URL: https://pm.gc.ca/en/mandate-letters/2021/01/15/ minister-families-children-and-social-development-supplementary-mandate [October 2, 2021].

Syed, F. (2021, April 23). Budget 2021: How the sector fared. The Philanthropist Journal. URL: https://thephilanthropist .ca/2021/04/budget-2021-how-the-sector-fared/ [October 3, 2021].

War Child Canada. (2020, March 25). Canada's charities make urgent ask of Ottawa for $\$ 10$ billion stabilization fund [News release]. URL: https://www.newswire.ca/news-releases/canada-s-charities-make-urgent-ask-of-ottawa-for -10-billion-stabilization-fund-their-very-survival-at-risk-883821654.html [September 22, 2021].

\section{ABOUT THE AUTHORS / LES AUTEURS}

Cathy Barr is Vice-President, Research \& Strategic Relationships at Imagine Canada. Email: cbarr@imaginecanada.ca

Bernadette Johnson is Director, Advocacy \& Knowledge Mobilization at Imagine Canada. Email: bjohnson@imaginecanada.ca 